\title{
ANALISIS KUALIFIKASI, KOMPETENSI TUTOR/PENDIDIK DAN PROFIL PENGELOLA PENDIDIKAN KESETARAAN PADA PKBM DI DKI JAKARTA
}

\begin{abstract}
Anan Sutisna*
Abstract

The purpose of this study is to describe the data of the educational qualification, tutor's competence, and the administrators in equalizing education. This study is based on the fact tutors and the executing staff play a very important role in improving the instructional services. The study employed survey method with descriptive technique and questionaire. The study took place in PKBM in Jakarta on April to September 2011, with the research subjects include tutors and administrators. The findings indicate that the tutor's qualification has met the requirement but there is a mismatch between the educational specialization and the courses to teach, the tutor's competence is regarded low (at the average of 37,3 ) in pedagogy and andragogy and the administrators consist of head, secretary, and administrative staff as well as the educational staff.
\end{abstract}

Keywords: qualification, tutor's competence, administrator

\begin{abstract}
Abstrak
Tujuan penelitian ini adalah mendeskripsikan data tentang kualifikasi pendidikan, kompetensi tutor, dan pengelola pendidikan kesetaraan. Dasar penelitian ini adalah bahwa keberadaan tutor dan tenaga kependidikan sangat penting dalam meningkatkan kualitas layanan pembelajaran. Penelitian ini menggunakan metode survei dengan teknik deskriptif dan instrumen angket. Lokasi penelitian ini pada Pusat Kegiatan Belajar Masyarakat (PKBM) di Provinsi DKI Jakarta bulan April sampai dengan September 2011 dengan subjek penelitian tutor dan pengelola. Hasil penelitian menunjukkan bahwa kualifikasi pendidikan tutor sudah memenuhi standar (D-IV/S1) tetapi masih terjadi ketidaksesuaian (miss-macth) antara keahlian dengan bidang tugas dalam mengajar, kompetensi tutor masih lemah (rata-rata 37,3) terutama kemampuan pedagogi dan andaragogi, profil pengelola pendidikan kesetaraan secara umum terdiri dari ketua, sekretaris dan tenaga administrasi, serta tenaga pendidik.
\end{abstract}

Kata-kata kunci: kualifikasi, kompetensi tutor, pengelola pendidikan kesetaraan

\section{PENDAHULUAN}

Menurut Undang-Undang Nomor 20 Tahun 2003 tentang Sistem Pendidikan Nasional bahwa pendidikan nasional dilakukan melalui pendidikan formal dan pendidikan nonformal (PNF). Pendidikan nonformal adalah jalur pendidikan di luar pendidikan formal yang dapat dilaksanakan secara terstruktur dan berjenjang dan berfungsi untuk mengembangkan potensi peserta didik dengan penekanan pada pengetahuan akademik dan keterampilan fungsional serta pengembangan sikap dan kepribadian professional. Dalam rangka mendukung pendidikan sepanjang hayat, maka program pendidikan nonformal sebagai pendidikan alternatif untuk memberikan kesempatan kepada seluruh warga masyarakat yang tidak bisa dilayani pada pendidikan formal. Salah

\footnotetext{
* Dosen Jurusan Pendidikan Luar Sekolah Fakultas IImu Pendidikan UNJ
}

satu program PNF adalah Pendidikan Kesetaraan di mana penekanan program PNF terletak pada penguasaan pengetahuan dan keterampilan fungsional serta pengembangan sikap dan kepribadian professional. Hasil PNF dihargai setara dengan pendidikan formal setelah melalui proses ujian kesetaraan. Keberhasilan pelaksanaan kegiatan pembelajaran pendidikan keaksaraan khususnya Paket $C$ di lingkungan pendidikan nonformal akan sangat ditentukan oleh tutor/ pendidik dan penyelenggara sebagai pendidik dan tenaga kependidikan nonformal pada Pusat Kegiatan Belajar Masyarakat (PKBM). Ketersedian pendidik dan tenaga kependidikan non formal pada tahun 2008 telah tercatat di selu-ruh Indonesia sebanyak 8.968 orang. Sedangkan di Provinsi DKI Jakarta tutor pendidikan kesetaraan Program Paket $\mathrm{C}$ sebanyak 522 orang yang tersebar 
di lima wilayah DKI Jakarta, dari jumlah yang ada $30 \%$ belum memenuhi kualifikasi minimal ( $\mathrm{S} 1$ atau D-IV) dan $60 \%$ tidak sesuai dengan bidang tugas atau terjadi miss macth (Syamsudin: 2008).

Dalam kajian ini, tenaga pendidik dan kependidikan pendidikan nonformal dibatasi pada kualifikasi pendidikan dan kompetensi tutor/ pendidik dan profil penyelenggara kesetaraan untuk Program Paket $C$ pada PKBM. Tutor kesetaraan dalam pedoman pemetaan kompetensi pendidik dan tenaga kependidikan melalui Lembaga Penjamin Mutu Pendidikan (LPMP) adalah tenaga yang berasal dari masyarakat yang bertugas dalam merencanakan, melaksanakan, dan mengevaluasi proses pembelajaran pada pendidikan kesetaraan.

Adapun fokus penilitian ini dapat dirumuskan sebagai berikut.

1. Apakah kualifikasi pendidikan para tutor/ pendidik pada Program Kesetaraan Paket $C$ sudah sesuai dengan standar yang diharapkan?
2. Bagaimanakah gambaran tentang kompetensi tutor/ pendidik pada Program Kesetaraan Paket C ?

3. Bagaimanakah profil penyelenggaraan Pendidikan Kesetaraan Paket $C$ pada Pusat Kegiatan Belajar Masyarakat di DKI Jakarta?

Manfaat penelitian ini secara teoritis adalah menambah khasanah pengetahuan tentang pemetaan kualifikasi pendidikan dan pengembangan kompetensi tutor pendidik serta tenaga kepenididikan pendidikan kesetaraan khususnya Program Paket C. Sedangkan secara praktis adalah memberikan informasi kepada pihak pemangku kebijakan tentang kualifikasi pendidikan, kompetensi tutor/ pendidik dan penyelengaraan Program Paket $C$ sehingga secara khusus dapat bermanfaat bagi bidang PNFI sebagai pembina para tutor/ pendidik Paket $C$ dalam pengembangan kompetensinya, sekaligus dapat dijadikan landasan dalam kebijakan pengembangan pendidik dan tenaga kependidikan PNFI.

\section{KAJIAN TEORETIS}

\section{Hakikat Teori Kompetensi}

Kompetensi didefinisikan (Mitrani, et.al, 1992; Spencer, 1993) sebagai an underlying characteristic's of an individual which is causally related to criterionreferenced effective and or superior performance in a job or situation (karakteristik yang mendasari seseorang dan berkaitan dengan efektifitas kinerja individu dalam pekerjaannnya). Berangkat dari pengertian tersebut, kompentensi seorang individu merupakan sesuatu yang melekat dalam dirinya yang dapat digunakan untuk memprediksi tingkat kinerjanya. Menurut Sanghi (2007: 10) ada lima karakteristik dalam kompetensi seseorang yaitu.

1. Motives, yaitu sesuatu di mana seseorang secara konsisten berpikir sehingga melakukan tindakan. Mitrani, et.al (1992), menambahkan bahwa motives adalah "drive, direct, and select behavior toward certain action or goals and away from others".

2. Traits, yaitu watak yang membuat orang berperilaku atau merespon sesuatu dengan cara tertentu, seperti percaya diri (self confidence), kontrol diri (self control) dan ketabahan (stress resistance).

3. Self Concept, yaitu sikap dan nilai-nilai yang dimiliki seseorang.

4. Knowledge, yaitu pengetahuan yang dimiliki seseorang untuk bidang tertentu.

5. Skills, yaitu keterampilan atau kemampuan untuk melaksanakan suatu tugas tertentu baik secara fisik maupun mental.
Dari kelima karakteristik kompetensi tersebut kompetensi pengetahuan (knowledge) dan kompetensi keahlian (skill) cenderung bersifat lebih nyata (visible) dan relatif berada di permukaan sebagai salah satu karakteristik yang dimiliki manusia. Sedangkan konsep diri (self concept), watak (traits) dan motif (motives) kompetensi cenderung lebih tersembunyi dari dalam dan berada pada titik central kepribadian seseorang.

Selanjutnya menurut Spencer (1993) kompetensi dapat dibagi atas dua kategori yaitu "threshold competencies" dan "differentiating compentencies". threshold competencies adalah karakteristik utama yang harus dimiliki oleh seseorang agar dapat melaksanakan pekerjaannya, tetapi tidak untuk membedakan seseorang yang berkinerja tinggi dan rata-rata. Sedangkan "differentiating competiencies" adalah faktor-faktor yang membedakan individu yang berkinerja tinggi dan rendah. Misalnya seorang tutor harus mempunyai kemampuan utama mengajar, itu berarti pada tataran "threshold competencies". Selanjutnya, apabila tutor dapat mengajar dengan baik, cara mengajarnya mudah dipahami dan analisanya tajam sehingga dapat dibedakan tingkat kinerjanya maka hal itu sudah masuk kategori "differentiating competencies".

Kompetensi tutor terdiri atas dua kelompok yakni kompetensi generik dan kompetensi spesifik. Kompetensi generik meliputi kompetensi pedagogi dan andragogi, kepribadian dan sosial, sedangkan kompetensi spesifik adalah kompetensi profesional. Kompetensi 
generik berlaku untuk semua jenis tutor, sementara kompetensi spesifik berlaku untuk masing-masing jenis tutor. Adapun elemen kompetensi tutor pendidikan kesetaraan khususnya Paket C meliputi (1) kompetensi pedagogi dan andragogi; (2) kompetensi kepribadian; (3) kompetensi sosial; dan (4) kompetensi profesional (BSNP, 2008).

Kompetensi Pedagogi dan Andragogi Tutor Paket C

Seorang tutor sebagai agen pembelajaran, perlu memiliki kemampuan (competency) khusus, kemampuan yang tidak mungkin dimiliki oleh orang yang bukan tutor, karena tugas mengajar bukan hanya menyampaikan informasi, tetapi suatu proses mengubah perilaku peserta didik atau warga belajar. Oleh karena itu, dalam proses pembelajaran terdapat kegiatan membimbing warga belajar agar berkembang sesuai dengan tugas perkembangannya, melatih keterampilan, baik keterampilan intelektual maupun keterampilan motorik, memotivasi warga belajar agar tetap semangat menghadapi berbagai rintangan dan tantangan, serta kemampuan merancang dan menggunakan berbagai media dan sumber belajar untuk menambah efektivitas mengajarnya.

Kemampuan-kemampuan tersebut harus dimiliki tutor, maka tugas tutor adalah sebagai tugas profesional, yakni sebagai tugas yang hanya dilakukan oleh orang-orang tertentu, sesuai apa yang diungkapkan Cooper, 1990 (dalam Sanjaya, 2005: 142) bahwa " $A$ professional is a person who processes some specialized knowledge and skills, can weight alternatives and can select from among a number of potentially productive actions one that is particularly appropriate in a given situation."

Peneliti meyakini bahwa pekerjaan tutor adalah pekerjaan profesional yang memiliki karakteristik (1) pekerjaan ditunjang oleh suatu ilmu tertentu secara mendalam; (2) pekerjaan yang menekankan pada suatu keahlian dalam bidang tertentu yang spesifik sesuai dengan profesinya; (3) tingkat kemampuan dan keahlian dalam melaksanakan tugas pekerjaannya didasarkan pada latar belakang pendidikan tertentu yang diakui; dan (4) pekerjaan yang dibutuhkan oleh masyarakat dan memiliki dampak terhadap sosial kemasyarakatan.

Seorang tutor dalam melaksanakan tugas mengajarnya, perlu ditunjang dengan kompetensi yang cukup, sesuai yang diungkapkan oleh Johnson (dalam Sanjaya, 2005: 108) bahwa "Competency as rational performance which satisfactorily meets the objective for a desired condition". Menurutnya, bahwa kompetensi merupakan perilaku rasional untuk mencapai tujuan yang dipersyaratkan sesuai dengan kondisi yang diha- rapkan. Dengan demikian, suatu kompetensi ditunjukkan oleh penampilan atau unjuk kerja (performance) yang dapat dipertanggungjawabkan dalam rangka mencapai suatu tujuan.

Sanjaya (2005: 145-146) menjelaskan bahwa tugas tutor sebagai suatu profesi, terdapat sejumlah kompetensi yang harus dimiliki oleh seorang tutor, yakni kompetensi kepribadian, profesional, dan sosial kemasyarakatan. Kompetensi kepribadian, merupakan kompetensi yang berhubungan dengan pengembangan kepribadian (personal competencies), yang meliputi antara lain (1) kemampuan yang berhubungan dengan pengamalan ajaran agama sesuai dengan keyakinan agama yang dianutnya; (2) kemampuan untuk berperilaku sesuai dengan norma, aturan, dan sistem nilai yang berlaku di masyarakat; (3) mengembangkan sifatsifat terpuji sebagai seorang tutor, misalnya sopan santun dan tata krama; dan (4) bersikap demokratis dan terbuka terhadap pembaruan dan kritik.

Dalam Peraturan Pemerintah Nomor 19 tahun 2005 tentang Standar Nasional Pendidikan, khususnya pada pasal 28 ayat 3 , dijelaskan bahwa kompetensi pendidik sebagai agen pembelajaran meliputi kompetensi pedagogik, kompetensi kepribadian, kompetensi profesional, dan kompetensi sosial. Selanjutnya, dijelaskan bahwa kompetensi pedagogi adalah kemampuan mengelola pembelajaran peserta didik yang meliputi pemahaman peserta didik, perancangan dan pelaksanaan pembelajaran, dan evaluasi pembelajaran. Kompetensi kepribadian adalah kemampuan kepribadian yang mantap, stabil, dewasa, arif dan berwibawa, menjadi teladan bagi peserta didik, dan berakhlak mulia. Kompetensi profesional adalah kemampuan penguasaan materi pelajaran secara luas dan mendalam yang memungkinkannya membimbing peserta didik memenuhi standar kompetensi yang ditetapkan. Kompetensi sosial adalah kemampuan pendidik sebagai bagian dari masyarakat untuk berkomunikasi dan bergaul secara efektif dengan peserta didik, sesama pendidik, orang tua peserta didik, dan masyarakat sekitar.

Tutor Pendidikan Kesetaraan Paket C secara minimal harus memiliki empat kompetensi tersebut di atas. Salah satu kompetensi yang penting dan harus dikuasai tutor adalah kompetensi pedagogi dan andragogi, di samping kompetensi lainnya. Kompetensi pedagogi dan andragogi tutor Program Paket $\mathrm{C}$ secara ideal sesuai standar yang harus dipenuhi meliputi (1) memahami peserta didik/ warga belajar, dengan indikator esensialnya adalah memahami warga belajar dengan memanfaatkan prinsip-prinsip perkembangan kognitif, memahami dengan prinsip-prinsip kepribadian, dan mengidentifikasi kebutuhan belajar warga belajar; (2) 
merancang pembelajaran, termasuk memahami landasan pendidikan untuk kepentingan pembelajaran. Subkompetensi ini memiliki indikator esensial, diantaranya menerapkan teori belajar dan pembelajaran, menentukan strategi pembelajaran berdasarkan karakteristik warga belajar, menerapkan prinsip-prinsip andragogi, memahami kompetensi warga belajar yang ingin dicapai, memahami materi pembelajaran, serta menyusun rancangan pembelajaran berdasarkan strategi yang dipilih; (3) melaksanakan pembelajaran, subkompetensi ini memiliki indikator esensial di antaranya menata latar (setting) pembelajaran, melaksanakan pembelajaran yang kondusif, serta menerapkan prinsip-prinsip andragogi; (4) merancang dan melaksanakan evaluasi pembelajaran, subkompetensi ini memiliki indikator esensial antara lain melaksanakan penilaian proses dan hasil belajar secara berkesinambungan dengan berbagai metode, menganalisis hasil penilaian proses dan hasil belajar untuk menentukan tingkat ketuntasan belajar, serta memanfaatkan hasil penilaian pembelajaran untuk perbaikan kualitas program pembelajaran pendidikan nonformal secara keseluruhan; dan (5) mengembangkan warga belajar untuk mengaktualisasikan berbagai potensi yang dimilikinya, subkompetensi ini memiliki indikator esensial diantaranya memfasilitasi warga belajar untuk mengembangkan berbagai potensi akadermk, dan memfasilitasi warga belajar untuk meningkatkan berbagai potensi nonakademik. (BSNP, 2008)

\section{Penyelenggaraan Pendidikan Kesetaraan}

Salah satu program pendidikan nonformal adalah
Pendidikan Kesetaraan, yang meliputi Program Kelompok Belajar Paket A setara SD, Kelompok Belajar Paket B setara SMP, dan Kelompok Belajar Paket C setara SMA. Pendidikan nonformal yang difokuskan dalam kajian ini adalah Program Pendidikan Kesetaraan Paket C. Pendidikan kesetaraan dimulai pada tahun 1980-an ketika pemerintah mencanangkan wajib belajar sembilan tahun, yaitu enam tahun di SD dan tiga tahun di SLTP atau yang sederajat. Pada saat itu pendidikan nonformal meluncurkan Program Paket A setara SD dan Program Paket B setara SLTP. Kedua program tersebut dinilai memiliki urgensi dan keberhasilan yang signifikan sehingga pada tahun 2000 dilanjutkan dengan Program Paket $\mathrm{C}$ yang diperuntukkan bagi lulusan Paket B. Dalam perkembangan selanjutnya, program Paket $\mathrm{C}$ juga diperuntukkan bagi siswa sekolah formal yang tidak lulus SMA dan lulusan SMP yang ingin melanjutkan ke SMA. Sebagai bentuk pengakuan terhadap Program Paket C, pada tahun 2001 untuk pertama kali pemerintah menyelenggarakan ujian nasional Paket $\mathrm{C}$ yang kemudian pengakuan pengesahannya dilakukan pada tahun 2004 (Direktorat Pendidikan Kesetaraan, 2006).

Dalam penyelenggaraannya, program pendidikan kesetaraan dilakukan pada Pusat Kegiatan Belajar Masyarakat (PKBM), di mana ada beberapa komponen dalam pelaksanaan pembelajaran Paket $C$ yaitu (1) penyelenggara; (2) warga belajar Program Paket C; (3) tutor/pendidik; (4) sarana dan prasarana; (5) kurikulum kegiatan pembelajaran Program Paket C (Sutisna, 2010).

\section{METODOLOGI PENELITIAN}

\section{Tujuan Penelitian}

Tujuan secara umum penelitian ini adalah untuk memperoleh gambaran tentang kualifikasi pendidikan, kompetensi tutor/ pendidik dan pengelola Pendidikan Kesetaraan Paket $C$ dalam melaksanakan tugas dan fungsinya secara optimal. Secara khusus, tujuan kajian ini untuk memperoleh data tentang (1) tingkat kualifikasi pendidikan tutor; (2) kompetensi pedagogi dan andragogi tutor/ pendidik; dan (3) profil pengelola pendidikan kesetaraan Paket C.

\section{Metode Penelitian}

Metode yang digunakan dalam penelitian ini adalah survei dengan teknik deskriptif. Pengkajian ini merupakan penelitian deskriptif (Sugiyono, 2007), karena penelitian ini diarahkan guna memberi gambaran secermat mungkin mengenai individu, suatu keadaan, gejala maupun kelompok tertentu. Dalam hal ini, untuk menggambarkan kualifikasi pendidikan, kompetensi tutor/pendidikan dan penyelenggara pendidikan kesetaraan khususnya Paket $C$ pada PKBM.

\section{Tempat dan Waktu Penelitian}

Tempat dilakukannya penelitian ini yaitu Pusat Kegiatan Belajar Masyarakat (PKBM) di DKI Jakarta. Adapun waktu pelaksanaan penelitian ini selama enam bulan terhitung bulan April sampai September 2011.

\section{Populasi dan Sampel}

Populasi penelitian ini adalah kelompok belajar Paket $C$ pada PKBM di DKI Jakarta. Pemilihan sampel kelompok belajar dilakukan secara purposive, dengan kriteria kelompok belajar berada pada PKBM pelat merah sebanyak dua dan PKBM swasta sebanyak dua. Jumlah sampel kelompok belajar sebanyak empat PKBM yaitu (1) PKBM 15 Cideng dan Kelompok Belajar pada PKBM Al Ishlah Jakarta Pusat; (2) PKBM 17 
Penjaringan Jakarta Utara; dan (3) PKBM Miftahul Jannah Jakarta Timur. Di setiap wilayah kota diambil 10 tutor Paket $C$ sehingga sampel seluruhnya berjumlah 30 orang.

\section{Teknik Pengumpulan Data}

Pengumpulan data dilakukan melalui observasi, penyebaran angket, dan dokumentasi. Instrumen angket tersebut untuk menilai kompetensi pedagogi dan andragogi menggunakan peringkat selalu, kadang-kadang, dan tidak pernah. Di mana tiga kategori memiliki bobot sebagai berikut selalu $=3$, kadang-kadang $=2$, dan tidak pernah $=1$. Kemudian setelah skor/ bobot tersebut ditabulasi dan diolah, maka akan diketahui rata-rata dijadikan dasar untuk menyusun kriteria kompetensi tutor Paket C.

Teknik Analisis Data
Analisis data dilakukan secara kuantitatif yaitu melakukan perhitungan persentase dengan teknik yang digunakan deskriptif yaitu menjelaskan fenomena yang terjadi. Oleh karena itu, setelah data dikumpulkan dan dianalisis untuk mengetahui kualifikasi pendidikan, kompetensi tutor/ pendidik Program Paket $\mathrm{C}$ dengan menggunakan formula rumus prosentasi sebagai berikut.

$$
P=\frac{\sum X i}{N}
$$

Keterangan :

$$
\begin{array}{ll}
P & : \text { Persentase data } \\
\sum_{N} X i & : \text { Jumlah data yang masuk } \\
& \text { : Jumlah responden yang diteliti }
\end{array}
$$

\section{HASIL PENELITIAN}

Hasil penelitian berdasarkan focus masalah yang dirumuskan dan tujuan penelitian yang hendak dicapai, maka hasilnya akan diuraikan lebih lanjut di bawah ini sebagai berikut.

\section{Kualifikasi Pendidikan Tutor/Pendidik}

Studi kajian ini dilakukan di Dinas Pendidikan Nasional Propinsi DKI Jakarta, khususnya di Bidang Pendidikan Nonformal dan Informal, yaitu melalui Kepala seksi Pendidikan Kesetaraan. Di mana di DKI Jakarta, tercatat data tentang PKBM penyelenggara Program Paket $C$ tahun 2008 yang melaksanakan pendi-dikan kesetaraan sebanyak 154 PKBM yang tersebar di Jakarta, dengan jumlah tutor 522 orang tutor dengan berbagai kualifikasi pendidikan yang beragam mulai dan kualifikasi SLTA, Diploma, S1, dan S2. Profil kualifikasi pendidikan tutor berdasarkan data tersebut dapat dilihat dalam tabel sebagai berikut.

Tabel 1. Data Kualifikasi Pendidikan Tutor Paket C

Sumber: Dinas Pendidikan Nasional Propinsi DKI Jakarta (2008)

Berdasarkan data dalam tabel di atas, diketahui bahwa persentase tertinggi kualifikasi tutor adalah kualifikasi S1 (71,84\%). Menurut penuturan Kasi Pendidikan Kesetaraan (Drs. Budi) kualifikasi tersebut umumnya adalah dari program $\mathrm{S} 1$ nonpendidikan.
Urutan kedua adalah kualifikasi Diploma/ Sarjana Muda $(20,3 \%)$, dan kualifikasi S2 (2,68\%). Dalam konteks implementasi Program Pendidikan Kesetaraan Paket $C$, kenyataan ini menunjukkan bahwa kualifikasi tutor (qualifled) dan ketidakcocokan (miss match) antara bidang keahlian tutor di PKBM dengan tugas mengajarnya dalam pendidikan kesetaraan paket $C$ pada PKBM tersebut, serta ditambah dengan latar belakang pendidikan tutor $75 \%$ S1-nya dari nonkependidikan.

Data yang diperoleh dari penyebaran angket terhadap tutor kesetaraan Paket $\mathrm{C}$ sebanyak 30 orang tutor masing-masing mewakili PKBM, diperoleh 1 orang tutor $(3,3 \%)$ berkualifikasi SLTA, 3 orang tutor (10\%) berkualifikasi Diploma/ Sarjana Muda, dan 25 orang tutor $(83,3 \%)$ berkualifikasi S1, serta 1 orang tutor $(3,3 \%)$ berkualifikasi S2. Temuan tersebut juga menunjukkan sebagian besar tutor kualifikasinya sudah qualified dan hanya keahlian mengajarnya yang masih miss match. Kondisi ini makin memperkuat sinyal elemen bahwa mutu pembelajaran dalam penyelenggaraan Paket $C$ pada PKBM rendah dan sekaligus memperkuat anggapan bahwa pengembangan dan peningkatan kompetensi tutor pada PKBM dibutuhkan.

Terkait dengan standar tutor sebagaimana yang dipersyaratkan dalam Peraturan Pemerintah Republik Indonesia Nomor 19 Tahun 2005, tutor adalah pendidik yang harus memiliki kualifikasi akademik dan kompetensi sebagai agen pembelajaran. Mengacu pada pasal 29 pada peraturan tersebut, kualifikasi akademik minimal tutor kesetaraan Paket C adalah D-IV atau S1. Berdasarkan data temuan hasil survei, sebagaimana dijelaskan di atas dan dalam konteks implementasi 
program kesetaraan Paket C, jika dikaitkan dengan ketentuan yang disebutkan dalam peraturan pemerintah tersebut, jelas bahwa tutor kesetaraan Paket $\mathrm{C}$ di PKBM sebagian besar $(83,3 \%)$ telah memenuhi standar kualifikasi akademik minimal sebagaimana yang dipersyaratkan. Sedangkan di sisi lain masih terjadinya miss macth bidang keahlian tutor dengan tugas yang dilakukan dalam pembelajaran mencapai $(75 \%)$ mengakibatkan tidak terpenuhinya standar kompetensi sebagai tenaga tutor seharusnya.

\section{Kompetensi Pedagogi dan Andragogi Tutor}

Untuk memperoleh gambaran tentang profil kompetensi tutor, pada kegiatan studi kajian ini dengan melakukan survei terhadap 30 orang tutor yang masingmasing sebagai perwakilan dari masing-masing PKBM di DKI Jakarta. Deskripsi tentang profil kompetensi tutor diangkat dari jawaban tutor melalui kuesioner yang diberikan. Hasil analisis menunjukkan penguasaan kompetensi pedagogi dan andragogi tutor rata-rata hanya $37,3 \%$ (masih lemah). Kompetensi tutor diketahui berdasarkan pemahaman dan persepsi tutor terhadap indikator kompetensi. Temuan survei dalam studi kajian dapat dideskripsikan sebagai berikut.

1. Mengembangkan kompetensi melalui pelatihan menunjukan sebesar 63,3 .\% dan pemahaman terhadap kurikulum pendidikan keseteraan $10 \%$.

2. Melaksanakan penyusunan program tahunan $6,7 \%$, program semester $20 \%$, silabus mata pelajaran $20 \%$, dan persiapan mengajar $26,7 \%$.

3. Melaksanakan penjabaran kurikulum ke dalam program pembelajaran $10 \%$ dan memahami menyusun persiapan mengajar $30 \%$.

4. Selalu meningkatkan penguasaan materi pembelajaran $40 \%$, selalu mengembangkan materi pembelajaran $30 \%$, selalu menggunakan media $46,7 \%$, selalu membuat media sediri $10 \%$, dan selalu menggunakan sumber belajar $40 \%$.

5. Melaksanaan bimbingan terhadap warga belajar menunjukkan $56,7 \%$ dan selalu membuat rencana bimbingan dan konseling pada warga belajar $26,7 \%$.

6. Melasanakan penyusunan tes hasil belajar $40 \%$, selalu melaksanakan evaluasi formatif $33,3 \%$, dan selalu menyusun ringkasan mater pembelajaran $43,3 \%$.

7. Mengembangkan potensi dan prestasi warga belajar $26,7 \%$ dan selalu merencanakan untuk mengembangkan data hasil belajar $76,6 \%$.

8. Melaksanakan pembelajaran sesuai rencana pembelajaran $26,7 \%$, pembelajaran yang dilaksanakan selalu sistematis $30,0 \%$, selalu menggunakan metode mengajar yang variatif $40 \%$, selalu memberikan latihan $50 \%$, dan selalu memotivasi warga belajar dalam pelaksanaan pembelajaran $23,3 \%$.

9. Terjadi interaksi antara tutor dan warga belajar $73,3 \%$, selalu membuat rencana persiapan pembelajaran sesuai karakteristik warga belajar $76,7 \%$, selalu memanfaatkan internet dalam pembelajarannya $70,0 \%$, selalu memanfaatkan sumber belajar yang ada dilingkungan $73,3 \%$, dan tidak pernah melakukan kegiatan remedial $6,7 \%$.

\section{Profil Pengelola Pendidikan Kesetaraan}

Hasil survei pada PKBM tersebut, hanya dua

PKBM masing-masing diuraikan lebih lanjut sebagai berikut.

1. PKBM 15 Cideng Jakarta Pusat

a. Data Umum PKBM 15 Cideng, PKBM ini didirikan sejak 12 Desember 1998 berdasarkan surat Kabid Diknas No.940/101/J/MX/98, nama awalnya adalah Panti Latihan Kerja (PLK 15) dengan nama PKBM 15 Cideng, beralamat di Jalan Cimanuk No. 3B, RT.016/01 Kelurahan Cideng, Kecamatan Gambir, Kota Administrasi Jakarta Pusat, Telp. (021) 3347140. Tipe PKBM ini adalah pelat merah alias punya Pemda DKI Jakarta. Pengelola PKBM ini adalah.

1) Ketua : Yulis Tri Astuti, S.Pd

2) Sekretaris : Wiwi, S.Pd

3) Bendahara: Ermawati, S.Pd

4) KaTU : A. Syahrul.

Penyelenggaraan PKBM ini adalah di bawah Kasi PNFI Sudin Dikdasmen Kotamadya Jakarta Pusat.

b. Warga Belajar PKBM 15 Cideng, jumlah warga belajar secara keseluruhan pada bulan Januari Juli 2009 mencapai 745 orang. Umumnya para warga belajar berasal dari wilayah sekitar PKBM. Jumlah warga belajar yang mengikuti program pendidikan kesetaraan pada tahun 2009 untuk Program Paket A dan B berjumlah 240 orang, untuk Program Paket C berjumlah 255 orang. Sedangkan sisanya sebanyak 250 warga belajar mengikuti Program Keaksaraan Fungsional 30 orang, kursus 115, dan PAUD 85 orang.

C. Ketenagaan PKBM 15 Cideng, jumlah tutor ada 42 orang, tenaga administrasi/Tata Usaha satu orang, dan satu orang petugas kebersihan. Sedangkan jumlah tutor pada implementasi Program Pendidikan Kesetaraan Paket A dan B sebanyak 19 orang dan tutor Paket $\mathrm{C}$ sebanyak 10 orang. Berdasarkan latar belakang pendidikan, tutor berlatar belakang S1 9 orang, Sarjana Muda/ Diploma 1 orang.

d. Sarana dan prasarana PKBM 15 Cideng, sarana berupa bangunan PKBM berdiri di atas tanah milik Pemda DKI Jakarta seluas 280 meter persegi, sedangkan luas seluruh tanahnya 560 meter per- 
segi. Dengan dilengkapi peralatan 17 unit komputer, 12 unit mesin jahit, 2 buah mesin obras, 3 buah printer, dan 1 buah mesin jahit high speed. Sedangkan ruang belajar ada 2 lokal yang dilengkapi dengan 40 meja dan kursi, 5 buah meja tutor dan 5 buah papan tulis whiteboard, serta dilengkapi 1 ruang pimpinan dan Ka. TU PKBM yang menggunakan 1 unit AC.

e. Pengelolaan Program Paket C pada PKBM 15 Cideng, menurut penuturan Ketua PKBM 15 Cideng bahwa, menyelenggarakan Program Paket $C$ dimulai pada tahun 2004 berdasarkan surat Keputusan Mendiknas. Nomor: 132/U/2004. Jumlah warga belajar yang mengikuti Program Pendidikan Kesetaraan Paket $C$ pada tahun 2009 sebanyak 255 orang. Penyelenggaraan Program Paket $C$ ini sesuai dengan panduan yang ada dari Departemen Pendidikan Nasional, bahwa bidang studi yang diajarkan baik secara tatap muka dalam bentuk klasikal maupun belajar mandiri melalui modul yang meliputi mata pelajaran agama, PPKn, matematika, IPA (biologi, fisika \& Kimia), sosiologi, bahasa Indonesia, dan bahasa Inggris, serta keterampilan (life skill).

f. Tutor Program Paket C PKBM 15 Cideng, jumlah tutor untuk Program Paket $C$ ada 10 orang, dan menurut penjelasan penanggungjawab PKBM, dilihat dari latar belakang pendidikannya, kualifikasi pendidikan tutor yang beragam. Berdasarkan dokumen di PKBM diketahui data tutor tersebut, dapat dideskripsikan dalam tabel sebagai berikut.

2. PKBM Miftahul Jannah

a. Data Umum PKBM Miftahul Jannah, PKBM ini didirikan sejak 17 Agustus 1998 dengan nama PKBM Miftahul Jannah, beralamat di Jalan H. Mugeni III Pisangan Lama III No. 1, RT.01/06 Kelurahan Pisangan Timur, Kecamatan Pulogadung, Kota Administrasi Jakarta Timur. Telp. (021) 4893740-404711064. PKBM ini di bawah Yayasan Miftahul Jannah yang bergerak dalam bidang pendidikan, keterampilan, dan keagamaan. Pimpinan PKBM ini adalah.
1) Ketua
: Hj.Ria Asrul
2) Wakil Ketua I
: Hj.Yuyun Zarkasih
3) Wakil Ketua II
: Hj.Yeni Suharsono,SE, MBA
4) Sekretaris I
: Latifah, SE,
5) Sekretaris II
: Lusia Soetanto.
5) Bendahara
: Hj. Rasmi Achmad.
6) Ka Bidang Pendidikan: $\mathrm{Hj}$. Lies A. Sujudi.
Penyelenggaraan PKBM ini adalah dibina oleh
Bidang PNFI Dinas Pendidikan Provinsi DKI Jakarta, dan Dinas Bintal \& Kesos DKI Jakarta.
b. Warga Belajar PKBM Miftahul Jannah berjumlah

783 orang secara keseluruhan pada bulan JanuariJuli 2009. Umumnya, para warga belajar berasal dari wilayah sekitar PKBM. Jumlah warga belajar yang mengikuti program pendidikan kesetaraan pada tahun 2009 untuk Program Paket A, B, dan C dan $\mathrm{KF}$ berjumlah 583 orang. Sedangkan sisanya sebanyak 100 warga belajar mengikuti program Taman Pendidikan Al-Qur'an dan 100 orang mengikuti program PAUD.

c. Ketenagaan PKBM Miftahul Jannah, jumlah tutor ada 40 orang, tenaga administrasi/ tata usaha satu orang, dan satu orang petugas kebersihan. Sedangkan jumlah tutor pada implementasi Program Pendidikan Kesetaraan Paket A dan B sebanyak 19 orang dan tutor Paket $C$ sebanyak 16 orang. Berdasarkan latar belakang pendidikan, tutor berlatar belakang S1 15 orang, dan Sarjana Muda/ Diploma 1 orang.

d. Sarana dan prasarana PKBM Miftahul Jannah, sarana berupa bangunan Masjid, Majelis Taklim dan PKBM berdiri di atas tanah hak milik seluas 820 meter persegi, sedangkan luas seluruh tanahnya 1500 meter persegi. Dengan dilengkapi peralatan 27 unit komputer, 12 unit mesin jahit, 4 buah mesin obras, dan 4 buah printer. Sedangkan ruang belajar ada 8 lokal yang dilengkapi dengan 40 meja dan kursi, 8 buah meja tutor, dan 8 buah papan tulis whiteboard. Serta dilengkapi ruang pimpinan dan Ka TU PKBM yang menggunakan AC.

e. Pengelolaan Program Paket $C$ pada PKBM Miftahul Jannah, menurut penuturan Ketua PKBM Miftahul Jannah bahwa, menyelenggarakan Program Paket C dimulai pada tahun 2004 berdasarkan surat Keputusan Mendiknas Nomor: 132/U/2004. Jumlah warga belajar yang mengikuti Program Pendidikan Kesetaraan Paket $C$ pada tahun 2009 sebanyak 210 orang. Penyelenggaraan Program Paket $C$ ini sesuai dengan panduan yang ada dari Departemen Pendidikan Nasional bahwa bidang studi yang diajarkan baik secara tatap muka dalam bentuk klasikal maupun belajar mandiri melalui modul yang meliputi mata pelajaran agama, PPKn, matematika, IPA (biologi, fisika \& Kimia), sosiologi, bahasa Indonesia, dan bahasa Inggris, serta keterampilan (life skill).

f. Tutor Program Paket $C$ pada PKBM Miftahul Jannah, jumlah tutor untuk Program Paket $C$ ada 10 orang, dan menurut penjelasan penanggung jawab PKBM, dilihat dari latar belakang pendidikannya, kualifikasi pendidikan tutor yang beragam. Berdasarkan dokumen di PKBM diketahui bahwa sembilan orang tutor sudah S1 dan satu orang tutor Sarjana Muda. 


\section{KESIMPULAN}

Berdasarkan hasil kajian tersebut di atas, maka dapat disimpulkan bahwa.

Pertama, kualifikasi pendidikan tutor/ pendidik kesetaraan Paket $\mathrm{C}$ dari 30 menunjukkan 1 orang tutor $(3,3 \%)$ berkualifikasi SLTA, 3 orang tutor (10\%) berkualifikasi Diploma/ Sarjana Muda, dan 25 orang tutor $(83,3 \%)$ berkualifikasi $\mathrm{S} 1$, serta 1 orang tutor $(3,3 \%)$ berkualifikasi S2. Hal ini menunjukkan sebagian besar tutor kualifikasinya sudah qualified tetapi dalam keahlian tidak sesuai dengan bidang tugas mengajarnya (miss match).

Kedua, kompetensi pedagogi dan andragogi tutor Paket $C$ rata-rata hanya $37,3 \%$ (masih lemah).
Ketiga, profil penyelenggaraan Program Paket C secara umum, di mana setiap PKBM penyelenggara Program Paket $\mathrm{C}$ dipimpin oleh seorang ketua dan sekretaris yang bantu oleh tenaga TU serta tenaga pendidik dengan kualifikasi pendidikan bervariasi. Dari data warga belajar yang ada di setiap PKBM berbeda jumlahnya dan umumnya para warga belajar berasal dari wilayah sekitar PKBM. Berkaitan dengan sarana dan prasarana, PKBM telah memenuhi standar minimal yaitu luas tanah, luas bangunan, peralatan komputer dan printer, ruang belajar yang dilengkapi meja dan kursi warga belajar, meja kursi tutor, dan papan tulis whiteboard.

\section{DAFTAR PUSTAKA}

BSNP. (2008). Draft standar tutor pendidikan kesetaraan. Jakarta: Depdiknas.

Depdiknas. (2006). Pendidikan kesetaraan. Jakarta: Direktorat Pendidikan Kesetaraan, Ditjen PLS.

Depdiknas. (2009). Pedoman pemetaan kompetensi PTK-PNF. Jakarta: Ditjen PMPTK.

Dinas Pendidikan. (2008). Kualifikasi pendidikan tutor paket C. Jakarta: Disdik Provinsi DKI Jakarta.

Mitrani, A., Daziel, M., \& Fitt, D. (1992). Competency based human resource management: Valuedriven strategies for recruitment, development and reward. London: Kogan Page Limited.

Peraturan Pemerintah Nomor 19 Tahun 2005 tentang Standar Nasional Pendidikan. Jakarta: Depdiknas.

Sanghi, S. (2007). The Handbook of competency mapping, understanding, designing, and implementing competency models in organizations. Asia-Pasific, Ltd: Sage
Publications.

Sanjaya, W. (2005). Pembelajaran dalam implementasi kurikulum berbasis kompetensi. Jakarta: Pernada Media.

Spencer, M. L., \& Spencer, M. S. (1993). Competence at work: Models for superrior performance. New York, USA: John Wily and Son. Inc.

Sugiyono. (2007). Metode penelitian kuantitatif, kualitatif dan $R$ \& $D$. Bandung: Alfabeta.

Sutisna, A. (2010). Pengembangan model pelatihan berbasis kinerja untuk peningkatan kompetensi tutor paket C pada PKBM di DKI Jakarta. Disertasi: UPI Badung.

Syamsudin, E. (2008). Percepatan peningkatan mutu tenaga pendidik dan kependidikan pendidikan nonformal, sesuai BSNP. Jakarta: Depdiknas.

Undang-Undang Nomor 20 Tahun 2003 tentang Sistem Pendidikan Nasional. Jakarta: Depdiknas. 